\title{
TRIMAČIO SPAUSDINIMO OTORINOLARINGOLOGIJOJE PERSPEKTYVOS
}

\author{
Nora Šiupšinskienè $\dot{1}^{1,2}$, Agnė Laukaitiene் $\dot{1}^{1}$, Urtė Norkutè-Macijauske் $\dot{1}^{1}$, Sigutė Norkiene் $\dot{1}^{1,3}$ \\ ${ }^{1}$ Klaipedos universiteto Sveikatos mokslu fakultetas, ${ }^{2}$ Lietuvos sveikatos mokslu universiteto \\ Medicinos akademijos Ausu, nosies ir gerklès ligu klinika, \\ ${ }^{3}$ Klaipédos jürininku ligonine
}

Raktažodžiai: trimatis spausdinimas, adityvus gaminimas, otorinolaringologija.

\begin{abstract}
Santrauka
Trimatis spausdinimas, arba adityvus gaminimas (angl. additive manufacturing) - tai vientiso, praktiškai bet kokios formos objekto gaminimo procesas iš skaitmeninio modelio, kai skirtingomis formomis sudedami sluoksniai. Nors ši technologija atsirado dar XX amžiaus devintame dešimtmetyje, iki XXI amžiaus antro dešimtmečio tokie spausdintuvai buvo naudojami tik komerciniais tikslais. Straipsnyje pateikiama mokslinès literatūros apžvalga apie trimačio spausdinimo tipus, technologijas ir trimačio spausdinimo panaudojimo galimybes otorinolaringologijoje.
\end{abstract}

\section{Ivadas}

Trimatis, arba (3D) spausdinimas, arba adityvus gaminimas (additive manufacturing) - tai trimačio, vientiso, praktiškai bet kokios formos objekto gaminimo procesas iš skaitmeninio modelio, kai skirtingomis formomis sudedami sluoksniai [1].

Nors ši technologija atsirado dar XX amžiaus devintame dešimtmetyje ir iki XXI amžiaus antro dešimtmečio tokie spausdintuvai buvo naudojami tik komerciniais tikslais. 3D spaudinimo technologiją pradejjo amerikiečių mokslininkas Chuck Hull 1986 metais savo ịkurtoje kampanijoje „3D Systems Corp“ [2]. Per pastaruosius kelis dešimtmečius ši technologija labai evoliucionavo, tapo populiari ir prieinama visuomenei.

Yra labai daug 3D spausdinimo pritaikymo sričių - ji svarbi architechtūroje, elektronikos pramonejje, komercinejje gamyboje, edukaciniuose procesuose ir, žinoma, odontologijoje ir medicinoje. Proceso metu „sluoksnis po sluoksnio“ dèliojamos įvairios medžiagos, tokios kaip plastikas, metalas, keramika, nailonas, akrilas, popierius, gyvi audiniai [1-3].

Šio darbo tikslas - atlikti šiuolaikinès literatūros analizę ir įvertinti trimačio spausdinimo technologijas, anatominius modelius bei šio metodo panaudojimo galimybes otorinolaringologijoje.

\section{Darbo metodika}

Atlikta duomenų paieška elektroninėse mokslinių duomenų bazèse PubMed, MEDLINE, EMBASE 2013-2018 metų laikotarpiu bei internetiniuose puslapiuose. Paieškos žodžiai: trimatis spausdinimas, 3D spausdinimas, adityvus gaminimas, otologija, rinologija, laringologija, otorinolaringologija. Atlikta trisdešimt keturių paskutinio penkmečio literatūros šaltinių apžvalga.

\section{Rezultatai ir jų aptarimas}

Technologijos. Šiandien yra daug 3D spaudinimo technologijų, tačiau kelios iš jų yra dažniausios:

- TIP - angl. thermal inkjet printing [3];

- FDM - angl. fused deposition modeling [4];

- SLS - angl. selective laser sintering [5].

TIP - „,bekontaktè technika“. Šiuose spausdintuvuose, kaitinant spausdintuvo galvutę, sukuriami maži oro burbulai, kuriems subliūkštant sukuriami spaudimo pulsai, jie išstumia rašalo „lašus“ iš išstūmoklio. Dydis - nuo 10 iki 150 pikolitrų. Dydis priklauso nuo temperatūros, pulso dažnio, rašalo klampumo (1pav.) [3].

Taikant FDM technologiją, vietoj ,rašalo“ naudojami išlydyti plastiko rutuliukai. Spausdintuvo galvutei judant išstumiamas plonas būsimo objekto sluoksnis, procesas kartojamas daug kartų [4]. Kadangi medžiaga kaitinama ją išstumiant, ji sulimpa su prieš tai buvusiu sluoksniu. Sluoksniai laipsniškai kietejja (2 pav.).

SLS - spausdinimo medžiaga miltelių pavidalo. Lazeris piešia objekto figūrą milteliuose, juos kaitindamas. Karto- 
jama pasluoksniui, kiekvienas sluoksnis dedamas aukščiau prieš tai buvusio. Procesas kartojamas, kol baigiamas objektas (3 pav.) $[5,6]$.

Pastaraisiais metais 3D spausdinimas pradètas naudoti ir otorinolaringologijoje. Pradèta medicininių implantų, protezų, edukacinių modelių gamyba pagal realių pacientų duomenis. Taip pat audinių ir organų gamyba, farmaciniai tyrimai [3-7].

Anatominiai modeliai. 3D spaudinimu sukuriami tikslūs anatominiai modeliai pagal individualią organo struktūrą. Modeliai gaminami pagal konkretaus paciento kompiuterinès tomografijos (KT) ir magnetinio rezonanso tyrimo (MRT) vaizdus [7-9]. Gaminiai iš dalies skaidrūs, pagaminti iš mažai

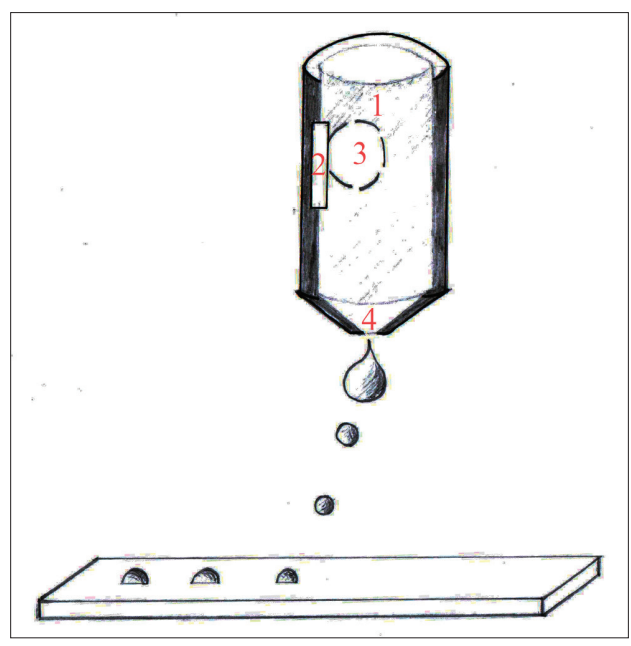

1 pav. Bekontaktès technikos (TIP) spausdinimo schema: 1 - rašalas, 2 - rezistorius, 3 - burbulas, 4 - purkštukas. Iliustracija: Nauris Laukaitis

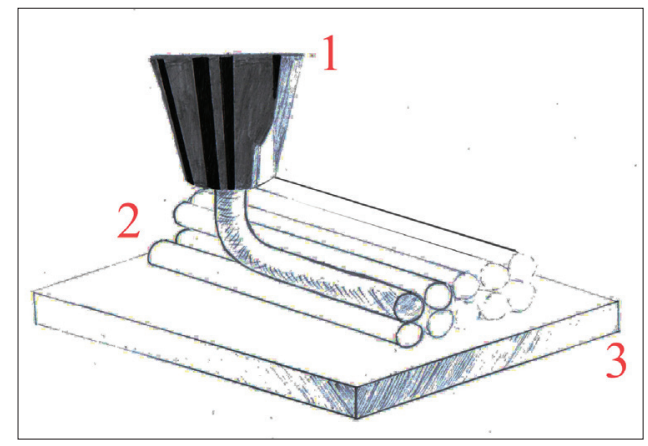

2 pav. FDM spausdinimo schema, kai vietoje "rašalo" naudojami išlydyti plastiko rutuliukai: 1 - purkštukas, išskiriantis išlydytą plastiką, 2 nusėdusi medžiaga (sumodeliuota dalis), 3 - kontroliuojamas kilnojamasis stalas. Iliustracija: Nauris Laukaitis kainuojančios akrilo dervos ar polivilalkoholio medžiagų, kurių sudètyje yra vandens ir jų tekstūra yra panaši i gyvus audinius, sukuriančius tikros chirurginės operacijos vaizdą. Jie - ekonomiški, aiškios struktūros - galimai be šalutinių ligų, juos galima naudoti neribotą kartų kiekį. Pavyzdžiui, mokslininkų sukurti nosies, sinusų ir kaukolès pamato modeliai naudojami endoskopinių operacijų treniravimuisi $[7,10-$ 12]. Otorinolaringologijos rezidentai turi galimybę išmokti tikslią operacijos techniką, atskirti simuliacinèse operacijose tokias svarbias anatomines struktūras kaip antai pleištinị antị, vidinę miego arteriją, regos nervą, turkišką balną ir pakylą. [10-12]. O sukurti smilkinkaulio modeliai igalina įsisavinti visų ausies dalių anatomiją, detaliai ịvertinti klausos kauliukų - plaktuko, priekalo ir kilpos topografinę anatomiją, ovalųji langą, speninę ataugą, pusratinius sraigès kanalus bei

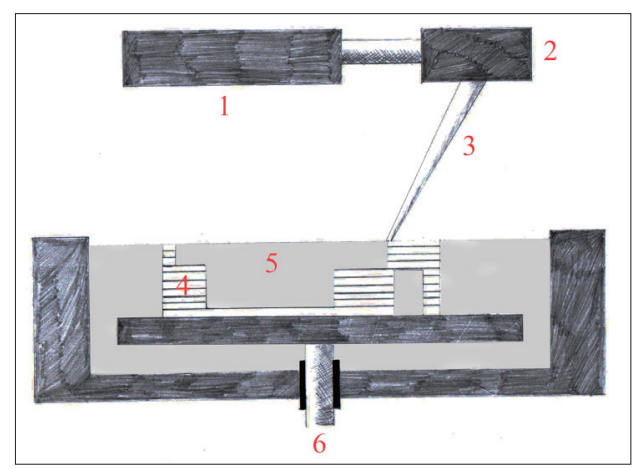

3 pav. Stereolitografijos prietaisas, 1 - lazeris, 2 - skenavimo sistema, 3 - lazerio spindulys, 4 - sukietejusi medžiaga, 5 - skysta medžiaga, 6 - platforma ir stūmoklis. Iliustracija: Nauris Laukaitis

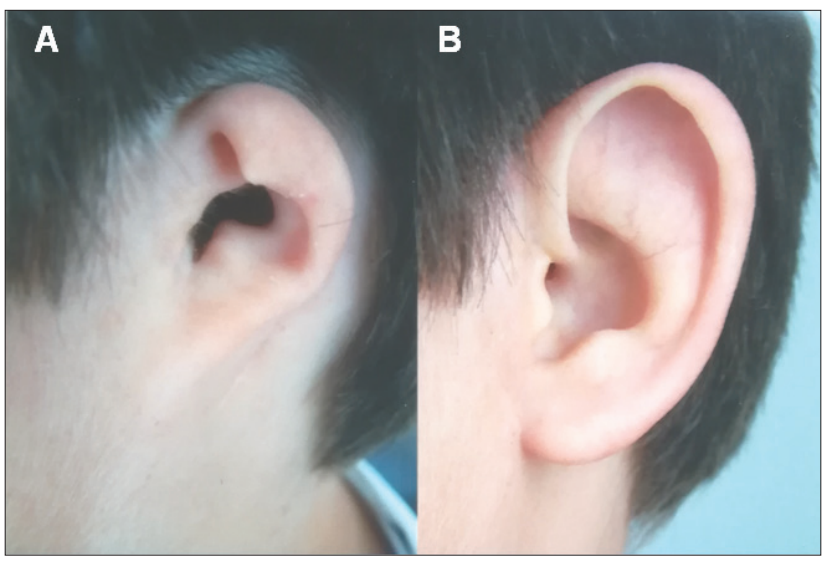

4 pav. Trimačiu spausdintuvu pagamintas ausies kaušelio protezas. A: kairio ausies kaušelio defektas; B - atkurtas ausies kaušelis, atsižvelgiant ị sveiką ausi (modelis iš Georgy G. Gion kompanijos medicalartprosthetics.com pavyzdžių) 
identifikuoti veidinio nervo kanalo eigą [13]. Neseniai buvo sukurti modeliai, skirti nosies tamponados praktikavimuisi. Tokie modeliai sujungti su hidrauline sistema, todèl galima stebèti priekines ir užpakalines etmoidines arterijas, stabdyti kraujavimą iš užpakalinès nosies dalies, pavyzdžiui, iš $a$. sphenopalatina ir priekinès dalies kraujavimą - iš Kiesselbach rezginio [14]. Taip pat 3D modelių naudojimas padeda pacientams geriau suprasti patalogijas, būsimas operacijas ir jų rezultatus. Pagerejja bendradarbiavimas tarp gydytojo ir paciento [15].

Otologija. 3D spausdinimas svarbus klausos atkūrimui. Apie 60 proc. lètinių vidurinès ausies ligų yra susiję su klausos kauliukų defektais, kurie lemia kondukcinį klausos sutrikimą [7]. Klausai grąžinti, esant indikacijų, galima naudoti klausos kauliukų protezus, kurie geresni už ịprastus, plastiškesni, ilgaamžiai, stabilesni, individualiai sukurti kiekvienam ligos atvejui [16-18]. 3D spausdinimą taip pat galima panaudoti klausos reabilitacijoje. Yra du pagrindiniai orinio laidumo šiuolaikinių klausos aparatų tipai: užausiniai ir įausiniai (kanaliniai). Pastarieji yra efekyvesni, tačiau ir brangesni, kadangi individualiai pritaikyti pagal paciento ausies landą $[7,19]$. Šiandien pasaulyje yra daugiau nei dešimt milijonų 3D spausdintuvu pagamintų klausos aparatų, kurie yra patogesni ir pigesni nei naudojant ịprastą gaminimo technologiją [19-21].

Lètinis vidurinès ausies uždegimas esti labai dažna patologija, kasmet paliečianti apie $30 \mathrm{mln}$. pacientų, iš kurių daliai pasireiškia būgnelio perforacijos, reikalingos chirurginès intervencijos. Šiandien perforacijos uždarymui dažniausiai naudojama $m$. temporalis fascija ar ausies kaušelio kremzlè [7]. Nors dažniausiai toks gydymas efektyvus, dèl šių audinių, ypač fascijos struktūros, būdingų defektų, pasitaiko reperforacijų. Daugiasluoksnis būgnelio lopas, sukurtas naudojant trimatị spausdinimą, gali pašalinti būgnelio plastikos naudojant $m$. temporalis fasciją trūkumus ir pagerinti operacijos baigtis [22]. Kozin ir bendraautorių tyrimas atskleide, kad trimačiu spausdinimu sukurtas būgnelio lopas turi panašias i $m$. temporalis fasciją akustines savybes, o jo mechaninès savybès yra geresnès už fascijos - sukurtas būgnelio lopas yra stipresnis ir atsparesnis deformacijoms [22]. Buvo atlikti tyrimai su šinšilomis ir 3D spausdintuvu sukurtais būgnelio lopais, naudojant fibroblastus ir epiderminius augimo faktorius [23]. Rezultatai parodè, jog visų gyvūnų gijimas sklandus, geros klausos galimybès. Remiantis šiais rezultatais galima tikètis ateityje 3D spausdinimo pritaikymo būgnelio perforacijų gydyme.

Šią naują technologiją galima panaudoti ir išorinès ausies rekonstrukcijai (4 pav.) [24, 25]. Apžvelgus užsienio literatūrą, rasta, jog yra trys pacientai, kuriems buvo atstatytas išorinès ausies vaizdas naudojant $3 \mathrm{D}$ technologijas. Pagal esamą išorinę ausị sukurtas tokios pačios struktūros, spalvos, dizaino implantas.

Rinologija. 3D spausdinimas taip pat svarbus rinologijoje, pirmiausia gydant nosies defektus ir nosies pertvaros perforacijas [26]. Pagal KT vaizdus sukuriamas virtualus trūkstamos dalies brèžinys ir pagal jị sukuriamas silikoninis protezas. Protezas gali būti didelis, nelygiais kraštais, atitinkantis perforaciją [27]. Literatūroje aprašomi mokslininku rezultatai - geri, nepriklausantys nuo chirurgo patirties. Buvo atlikti tyrimai su triušiais, kuomet buvo panaudoti 3D spausdintuvo atspausdinti nosies pertvaros implantai, i kuriuos įsodinti chondrocitai bei fibrinas [28]. Po trijų mėnesių stebètas teigiamas efektas, nekilo uždegiminių reakcijų.

Taip pat 3D spausdinimu buvo sukurti apatinio žandikaulio implantai. Pirmasis buvo įsodintas 83 metų vyrui, sergančiam apatinio žandikaulio osteomielitu, antrasis 29 metų vyrui, patyrusiam motociklo avariją [29]. Be to, SLS spausdintuvu buvo sukurtas titaninis implantas vyrui, sergančiam ameloblastoma. Praejjus vieneriems metams, nustatyti geri gijimo rezultatai - gera žandikaulio funkcija, veido simetriškumas [7]. Paskelbti pirmieji duomenys apie onkologinių pacientų, sergančių sinusų vėžiu, kuriems atlikta abipusè maksilektomija, pooperacinę gomurio defektų rekonstrukciją trimačiu spausdintuvu sukurtais protezais $[25,30]$.

Laringologija. 3D spausdinimu galima atkurti trachejos defektus [31]. Tracheomaliacija - dažna liga naujagimysteje, sukelianti sunkiai gydomą kvėpavimo nepakankamumą. JAV keliems kūdikiams buvo atspausdinti trachejjos-bronchų îtvarai $[32,33]$. KT tyrimų metų buvo nuskenuotos tikslios trachèjų formos ir pagal juos sukurti kompiuteriniai tuščiaviduriai įtvarai SLS spausdintuvu iš polikaprolaktono. Gaminant ịtvarus buvo atsižvelgta ne tik ị tai, kad jie būtų lankstūs ir jais galètų judèti oras, bet ir kad atitiktų kiekvieno berniuko augimo greiti, galètų temptis. Praejjus metams pooperaciniu komplikacijų nebuvo registruota [7, 25]. Žvelgiant ị ateitị, tai galètų būti puikus gydymo būdas onkologiniams pacientams, esant ūmioms būklèms, pavyzdžiui, gerklų stenozei, nereikalaujantis papildomos imunosupresijos, sumažinantis infekcijos riziką.

Naujausia sisteminė 3D spausdinimo medicinoje klinikinio veiksmingumo analizè, apèmusi laikotarpi iki 2017 metų sausio ménesio ir išanalizavusi 350 atrinktų tyrimų duomenis, parode, kad visose medicinos srityse trimatis spausdinimas buvo efektyvus [34]. Daugiausia tyrimų atlikta burnos ir veido ir žandikaulių chirurgijos srityse $(58,3$ proc. visų tyrimų), toliau seké raumenų ir kaulų sistemos tyrimai [23,7 proc.]. Tačiau autoriai pabrezžè, kad trūksta gero dizaino, aukšto įrodymų lygio tyrimų, kurie tinkamai pagrịstų trimačių printerių platesnį naudojimą medicinoje. 
Viena iš ateities vizijų būtų sukurti gerai funkcionuojančius organus, o tai dar nepavyksta dèl organų kraujotakos subtilybių, galimybių spausdinti organų dalis tik iš vienos medžiagos, nemaišant skirtingų medžiagų. Išsprendus šias problemas, tikimasi gerų baigčių ne tik otorinolaringologijoje, bet ir visoje medicinoje, naudojant 3D spausdinimą organų gamyboje ir implantavime.

\section{Išvados}

1. Šiandien trijų dimensijų spausdinimas otorinolaringologijoje naudojamas kuriant anatominius edukacinius modelius, planuojant sudettingas operacijas bei individualių protezų ir implantų gamybai.

2. Mokomieji anatominiai ir operaciniai modeliai igalina geresnị struktūrų vaizdinimą, gerina topografijos suvokimą; jų pagalba galima išmokti naujų operacijų, treniruoti chirurginius ịgūdžius, numatyti galimas operacijos rizikas ir išmokti jas spręsti taip gerinant pacientų gydymo kokybę.

3. Priešoperacinis individualių modelių sukūrimas padeda planuoti būsimas sudètingas operacijas, ypač onkologijoje, ir išvengti svarbių struktūrų pažeidimo operacijos metu.

4. Iki šiolei didelè dalis klinikinio pritaikymo tyrimų panaudojant rekonstrukcinius lopus, protezus ar implantus atlikti su gyvūnus ir tik nedaugelis yra pritaikyti tikriems pacientams. Todèl ateityje reikia gero dizaino klinikinių tyrimų, kurie pagrịstų trimačio audinių spausdinimo klinikinę ir ekonominę naudą.

\section{Literatūra}

1. Miller DT, Nye JS, editors. Defense 2045: Assessing the future security environment and implications for defense policymakers. CSIS Reports. Washington:Rowman \& Littlefield 2015; 24-28.

2. Liaw CY, Guvendiren M. Current and emerging applications of 3D printing in medicine. Biofabrication 2017; 9(2):024102. https://doi.org/10.1088/1758-5090/aa7279

3. Cui X, Boland T, D'Lima DD, Lotz MK. Thermal inkjet printing in tissue engineering and regenerative medicine. Recent Pat Drug Deliv Formul 2012;6(2):149-55. https://doi.org/10.2174/187221112800672949

4. Marro A, Bandukwala T, Mak W. Three-dimensional printing and medical imaging: a review of the methods and applications. Curr Probl Diagn Radiol 2016; 45(1):2-9. https://doi.org/10.1067/j.cpradiol.2015.07.009

5. Mazzoli A. Selective laser sintering in biomedical engineering. Med Biol Eng Comput 2013;51(3):245-56. https://doi.org/10.1007/s11517-012-1001-x

6. Shirazi SF, Gharehkhani S, Mehrali M, Yarmand H, Metselaar HS, Adib Kadri N. et al. A review on powder-based additive manufacturing for tissue engineering: selective lasersintering and inkjet 3D printing. Sci Technol Adv Mater 2015;16(3): 033502.

https://doi.org/10.1088/1468-6996/16/3/033502

7. Zhong N, Zhao X. 3D printing for clinical application in otorhinolaryngology. Eur Arch Otorhinolaryngol 2017;274(12):407989.

https://doi.org/10.1007/s00405-017-4743-0

8. Owusu JA, Boahene K. Update of patient-specific maxillofacial, implant. Curr Opin Otolaryngol Head Neck Surg 2015; 23(4):261-64.

https://doi.org/10.1097/MOO.0000000000000175

9. Zadpoor AA. Design for additive bio-manufacturing: from patient-specific medical devices to rationally designed metabiomaterials. Int J Mol Sci 2017;18(8):1607.

https://doi.org/10.3390/ijms18081607

10. Chan HH, Siewerdsen JH, Vescan A, Daly MJ, Prisman E, Irish JC. 3D rapid rototyping for otolaryngology-head and neck surgery: applications in image-guidance, surgical simulation and patient-specific modeling. PLoS One 2015;10(9):e0136370. https://doi.org/10.1371/journal.pone.0136370

11. Nogueira Júnior JF, Cruz DN. Real models and virtual simulators in otolaryngology: review of literature. Braz J Otorhinolaryngol 2010;76(1):129-35.

12. Chen G, Ling F. A new plastic model of endoscopic technique training for endonasal transsphenoidal pituitary surgery. Chin Med J (Engl) 2010;123(18):2576-79.

13. Cohen J, Reyes SA. Creation of a 3D printed temporal bone model from clinical CT data. Am J Otolaryngol 2015;36(5):61924. https://doi.org/10.1016/j.amjoto.2015.02.012

14. Chiesa Estomba CM, Gonzịlez Fernịndez I, Iglesias Otero MI. How we do it: anterior and posterior nosebleed trainer, the 3D printing epistaxis project. Clin Otolaryngol 2018;43(2):765-66. https://doi.org/10.1111/coa.12711

15. Sander IM, Liepert TT, Doney EL, Leevy WM, Liepert DR. Patient education for endoscopic sinus surgery: preliminary experience using 3D printed clinical imaging data. J Funct Biomater 2017; 8(2). pii: E13. https://doi.org/10.3390/jfb8020013

16. Kuru I, Maier H, Müller M, Lenarz T, Lueth TC. A 3D-printed functioning anatomical human middle ear model. Hear Res 2016;340:204-13.

https://doi.org/10.1016/j.heares.2015.12.025

17. Hirsch JD, Vincent RL, Eisenman DJ. Surgical reconstruction of the ossicular chain with custom 3D printed ossicular prosthesis. 3D Print Med 2017;3(1):7.

18. Kamrava B, Gerstenhaber JA, Amin M, Har-El YE, Roehm PC. Preliminary model for the design of a custom middle ear prosthesis. Otol Neurotol 2017;38(6):839-45. https://doi.org/10.1097/MAO.0000000000001403

19. Tognola G, Parazzini M, Svelto C, Galli M, Ravazzani P, 
Grandori F. Design of hearing aid shells by three dimensional laser scanning and mesh reconstruction. J Biomed Opt 2004;9(4):835-43.

https://doi.org/10.1117/1.1756595

20. Pai I, Rojas P, Jiang D, Obholzer R, Coward T. The use of 3D printed external and internal templates for Bonebridge implantation - technical note. Clin Otolaryngol 2017;42(5):1118-120. https://doi.org/10.1111/coa.12599

21. Mukherjee P, Cheng K3, Flanagan S, Greenberg S. Utility of $3 \mathrm{D}$ printed temporal bones in pre-surgical planning for complex Bonebridge cases. Eur Arch Otorhinolaryngol 2017;274(8):3021-28.

https://doi.org/10.1007/s00405-017-4618-4

22. Kozin ED, Black NL, Cheng JT, Cotler MJ, McKenna MJ, Lee DJ. et al. Design, fabrication, and in vitro testing of novel three-dimensionally printed tympanic membrane grafts. Hear Res 2016;340:191-203.

https://doi.org/10.1016/j.heares.2016.03.005

23. Kuo CY, Wilson E, Fuson A, Gandhi N, Monfaredi R, Jenkins A. et al. Repair of tympanic membrane perforations with customized bioprinted ear grafts using chinchilla models. Tissue Eng Part A 2018;24(5-6):527-35.

https://doi.org/10.1089/ten.tea.2017.0246

24. Bos EJ, Scholten T, Song Y, Verlinden JC, Wolff J, Forouzanfar T. et al. Developing a parametric ear model for auricular reconstruction: a new step towards patient-specific implants. J Craniomaxillofac Surg 2015;43(3):390-5. https://doi.org/10.1016/j.jcms.2014.12.016

25. Crafts TD, Ellsperman SE, Wannemuehler TJ, Bellicchi TD, Shipchandler TZ, Mantravadi AV. Three dimensional printing and its applications in otorhinolaryngology-head and neck surgery. Otolaryngol Head Neck Surg 2017;156(6):999-1010. https://doi.org/10.1177/0194599816678372

26. Onerci Altunay Z, Bly JA, Edwards PK, Holmes DR, Hamilton GS, O`Brien EK. et al. Three dimensional printing of large nasal septal perforations for optimal prosthetic closure. Am J Rhinol Allergy 2016; 30(4):287-93.

https://doi.org/10.2500/ajra.2016.30.4324

27. Choi YD, Kim Y, Park E. Patient-specific augmentation rhinoplasty using a three dimensional simulation program and three dimensional printing. Aesthet Surg J 2017;37(9):988-98.

https://doi.org/10.1093/asj/sjx046

28. Kim YS, Shin YS, Park DY, Choi JW, Park JK, Kim DH. et al. The application of three-dimensional printing in animal model of augmentation rhinoplasty. Ann Biomed Eng 2015; 43(9):2153-162.

https://doi.org/10.1007/s10439-015-1261-3
29. World's first patient- specific jaw implant [Internet] [žiūrèta 2018 spalio 30]. Available from: http:// www.layerwisecom/ the-worldsfirst-patient-specific-am-lower-jaw.

30. Tasopoulos T, Kouveliotis G, Polyzois G2, Karathanasi V. Fabrication of a 3D printing definitive obturator prosthesis: a clinical report. Acta Stomatol Croat 2017; 51(1):53-58. https://doi.org/10.15644/asc51/1/7

31. Kaye R, Goldstein T, Aronowitz D, Grande DA, Zeltsman D, Smith LP. Ex vivo tracheomalacia model with 3D printed external tracheal splint. Laryngoscope 2017;127(4):950-55. https://doi.org/10.1002/lary.26213

32. Kaye R, Goldstein T, Zeltsman D, Grande DA, Smith LP. Three dimensional printing: a review on the utility within medicine and otolaryngology. Int J Pediatr Otorhinolaryngol 2016; 89:145-48. https://doi.org/10.1016/j.ijporl.2016.08.007

33. Robert J. Morrison, Scott J. Hollister, Matthew F. Niedner. et al. Mitigation of tracheobronchomalacia with 3D printed personalized medical devices in pediatric patients. Sci Trans1 Med 2015;7(285):285ra64.

https://doi.org/10.1126/scitranslmed.3010825

34. Diment LE, Thompson MS, Bergmann JHM. Clinical efficacy and effectiveness of $3 \mathrm{D}$ printing: a systematic review. BMJ Open 2017;7(12):e016891.

https://doi.org/10.1136/bmjopen-2017-016891

\section{THE PERSPECTIVES OF THREE DIMENSIONAL PRINTING IN OTORHINOLARYNGOLOGY N.Šiupšinskienė, A.Laukaitienė, U.Norkutė-Macijauskė, S.Norkienè}

Key words: three dimensional printing, additive manufacturing, otorhinolaryngology.

Summary

Three dimensional 3D printing, also known as Additive Manufacturing (AM), refers to processes used to create a three dimensional objects'. Objects can be of almost any shape or geometry and typically are produced using digital model data from a 3D model or another electronic data source, when layers are composed of different shapes. Although this technology appeared in the middle of the nine decade of the $20^{\text {th }}$ century until the second decade of the $21^{\text {st }}$ century, such printers were used exclusively for commercial purposes. This paper provides an literature overview of the types of three dimensional printing, and the possibilities of using it in otorhinolaryngology.

Correspondence to: norai_s@yahoo.com

Gauta 2018-11-26 